\title{
Development of Myxobilatus legeri in cyprinid fishes
}

\author{
Kálmán Molnár \\ Veterinary Medical Research Institute, Hungarian Academy of Sciences, PO Box 18, H-1581 Budapest, Hungary
}

\begin{abstract}
The myxosporean Myxobilatus legeri (Cépède, 1905) is a common parasite of the urinary tract of cyprinid fishes living in natural waters of Hungary. The parasite's development comprises 2 stages: (1) vegetative proliferation, which takes place intracellularly in epithelial cells of collecting tubules of the kidney; (2) plasmodial sporogony, which occurs in the lumen of renal tubules, ureters and urinary bladder. The development of $M$. legeri follows a seasonal cycle. In most fishes the intracellular trophozoites appear in epithelial cells in autumn. In early spring trophozoites enter the lumen of tubules and form plasmodia containing 1 to 3 spores. In rud Scardinius erythrophthalmus the developmental cycle of $M$. legeri differs in that coelozoic developmental stages are already demonstrable in the autumn.
\end{abstract}

\section{INTRODUCTION}

Numerous myxosporean species parasitizing renal tubules and urinary bladder of fishes have been described (species of Myxidium, Hoferellus, Myxobilatus, Sphaerospora). There is abundant information concerning their spores and coelozoic plasmodia occurring in renal tubules. Recent results (Molnár 1980, 1984, Dyková \& Lom 1982, Clifton-Hadley et al. 1984، Kent \& Hedrick 1985, Lom \& Dyková 1985, 1986, Molnár et al. 1986, Molnár \& Kovács-Gayer 1986) indicate that these parasites may have intercellular and intracellular developmental stages preceding coelozoic plasmodia and pansporoblasts.

Myxobilatus spp. in cyprinids have recently been reported by Lom (1986) who, in addition to $M$. legeri and $M$. gobii Evlanov, 1981, described from tench Tinca tinca a new species, $M$. nostalgicus.

The present paper reports the demonstration of early, intraepithelial developmental stages of Myxobilatus legeri, in addition to its coelozoic plasmodia and spores, in urinary passages of cyprinids living in natural waters of Hungary.

\section{MATERIALS AND METHODS}

The kidneys of a total of 202 fishes belonging to 10 different species, primarily from Lake Balaton, were examined for Myxobilatus spp. Specimens (2 to $3 \mathrm{yr}$ old) of Abramis brama $(n=11)$, Alburnus alburnus $(n=67)$, Aspius aspius $(n=4)$, Blicca bjoerkna $(n=57)$, Gobio gobio $(n=6)$, Pelecus cultratus $(n=3)$, Rhodeus sericeus $(n=5)$, Rutilus rutilus $(n=28)$, Scardinius erythrophthalmus $(n=17)$ and Tinca tinca $(n=4)$ were examined. Examinations were performed throughout the year. In the present paper, however, only results of examinations performed in spring and autumn are included. Fishes were caught with a seine und transported alive to the laboratory where they were dissected. Small pieces were excised from the kidney and examined as impression preparations under a coverslip.

Mucus squeezed out from ureter and urinary bladder was examined for the presence of spores and plasmodia. For histological examination infected and suspect organs (small pieces of kidney, entire urinary bladder, and coiled ureter) were fixed in Bouin's solution. After embedding the organs in paraffin, $4 \mu \mathrm{m}$ thick sections were cut and stained with haematoxylin and eosin.

\section{RESULTS}

The majority of the cyprinid fishes examined ( 6 out of 10 species) proved to be infected by Myxobilatus plasmodia and spores (Table 1). The most severe infection was found in white bream Blicca bjoerkna. In spring 
Table 1. Incidence of Myxobilatus spores and plasmodia in urinary tract of cyprinid fishes

\begin{tabular}{|c|c|c|c|c|c|c|c|}
\hline \multirow[t]{2}{*}{ Fish species } & \multirow{2}{*}{$\begin{array}{c}\text { No. of } \\
\text { specimens } \\
\text { examined }\end{array}$} & \multirow{2}{*}{$\begin{array}{c}\text { March-April, } \\
\text { No. of in- } \\
\text { fected fish }\end{array}$} & \multirow{2}{*}{$\begin{array}{c}1986 \text { and } 1987 \\
\text { No. of unin- } \\
\text { fected fish }\end{array}$} & \multicolumn{2}{|c|}{$\begin{array}{l}\text { Time of examination } \\
\text { May, } 1986 \text { and } 1987\end{array}$} & \multicolumn{2}{|c|}{ November, 1987} \\
\hline & & & & $\begin{array}{l}\text { No. of in- } \\
\text { fected fish }\end{array}$ & $\begin{array}{l}\text { No. of unin- } \\
\text { fected fish }\end{array}$ & $\begin{array}{l}\text { No. of in- } \\
\text { fected fish }\end{array}$ & $\begin{array}{l}\text { No. of unin- } \\
\text { fected fish }\end{array}$ \\
\hline $\begin{array}{l}\text { Common bream. } \\
\text { (Abramis brama) }\end{array}$ & 11 & 4 & 1 & 0 & 6 & - & - \\
\hline $\begin{array}{l}\text { Bleak } \\
\text { (Alburnus alburnus) }\end{array}$ & 67 & $12(54 \%)$ & 10 & $4(10.2 \%)$ & 35 & 1 & 5 \\
\hline $\begin{array}{l}\text { White bream } \\
\text { (Blicca bjoerkna) }\end{array}$ & 57 & $25(92 \%)$ & 2 & $3(12 \%)$ & 21 & - & 6 \\
\hline Asp (Aspius aspius) & 4 & - & 2 & - & 2 & - & - \\
\hline $\begin{array}{l}\text { Gudgeon } \\
\text { (Gobio gobio) }\end{array}$ & 6 & 4 & 2 & - & - & - & - \\
\hline $\begin{array}{l}\text { Chekhon } \\
\text { (Pelecus cultratus) }\end{array}$ & 3 & - & 2 & - & 1 & -- & - \\
\hline $\begin{array}{l}\text { Bitterling } \\
\text { (Rhodeus sericeus) }\end{array}$ & 5 & - & 5 & - & -- & - & - \\
\hline $\begin{array}{l}\text { Roach (Rutilus } \\
\text { rutilus) }\end{array}$ & 28 & 7 & 3 & - & 12 & - & 6 \\
\hline $\begin{array}{l}\text { Rudd (Scardinius } \\
\text { erythrophthalmus) }\end{array}$ & 17 & 4 & 1 & - & 6 & 6 & - \\
\hline Tench (Tinca tinca) & 4 & - & 1 & - & - & - & 3 \\
\hline
\end{tabular}

the prevalence of infection in this fish was $92 \%$. Rudd Scardinius erythrophthalmus, roach Rutilus rutilus, common bream Abramis brama, and bleak Alburnus alburnus were also highly infected. Infection was most prevalent in early spring, primarily in April. At that time there were spore-containing plasmodia in ureters and urinary bladder. In March only a small fraction of the plasmodia contained spores. In May, however, only a few free spores were demonstrable in the urinary passages. The rudd was an exception: in the ureters of this fish species spores appeared in late autumn. Intracellular stages preceding the coelozoic plasmodia were found in 2 fish species: in rudd these developmental stages were demonstrable in November, in white bream they appeared in March. Infection. was easiest to monitor in white bream, the most severely infected fish species.

\section{Intracellular developmental stages in white bream}

Intracellular developmental stages occurred in epithelial cells of the distal collecting tubules of the kidney (Fig. 1). As a rule, infection was restricted to a given segment of the tubules. However, almost all epithelial cells present in this infected segment contained spherical trophozoites (Fig. 2), the most mature of which measured $10 \mu \mathrm{m}$ in diameter. Younger trophozoites were situated in the cytoplasm apical to the nucleus, and were separated from the lumen by a narrow cytoplasmic border. More mature forms (Figs. 2 and 3) compressed the nucleus of the deformed host cell which was often no longer discernible. Younger trophozoites were 3 to $4 \mu \mathrm{m}$ in diameter and contained 1 to 3 nuclei (Fig. 3), whereas in more mature trophozoites there were 10 to 14 peripherally situated nuclei. The nuclei of the trophozoites were about $2 \mathrm{um}$ in diameter, stained intensely with haematoxylin and eosin and, thus, were easily distinguishable from epithelial cells.

\section{Coelozoic plasmodia in the lumen of renal tubules of white bream}

Plasmodia similar to, but usually larger than, the intracellular trophozoites were often observed in the lumen of some tubular segments showing intraepithe-

Figs. 1 to 4 . Blicca bjoerka. Fig. 1. Collecting tubules of kidney; note Myxobilatus legeri trophozoites in epithelial cells; haematoxylin and eosin $(\mathrm{H}$. and E.) $\times 500$. Fig. 2. Collecting tubule of kidriey; note $M$. legeri trophozoites (i) near basal membrane; (e) nuclei of epithelial cells (H. and $\vec{E}$.), $\times 1300$. Fig. 3. Trophozoites of intracellular and coelozoic location in kidney; intracellular forms (i) contain 8 to 14 nuclei; note coelozoic stages (c) of similar structure in lumen of tubules (H, and E.), $\times 1300$.

Fig. 4. Plasmodia containing spores (s) in lumen of renal tubule $(\mathrm{H}$. and E.), $\times 1300$ 

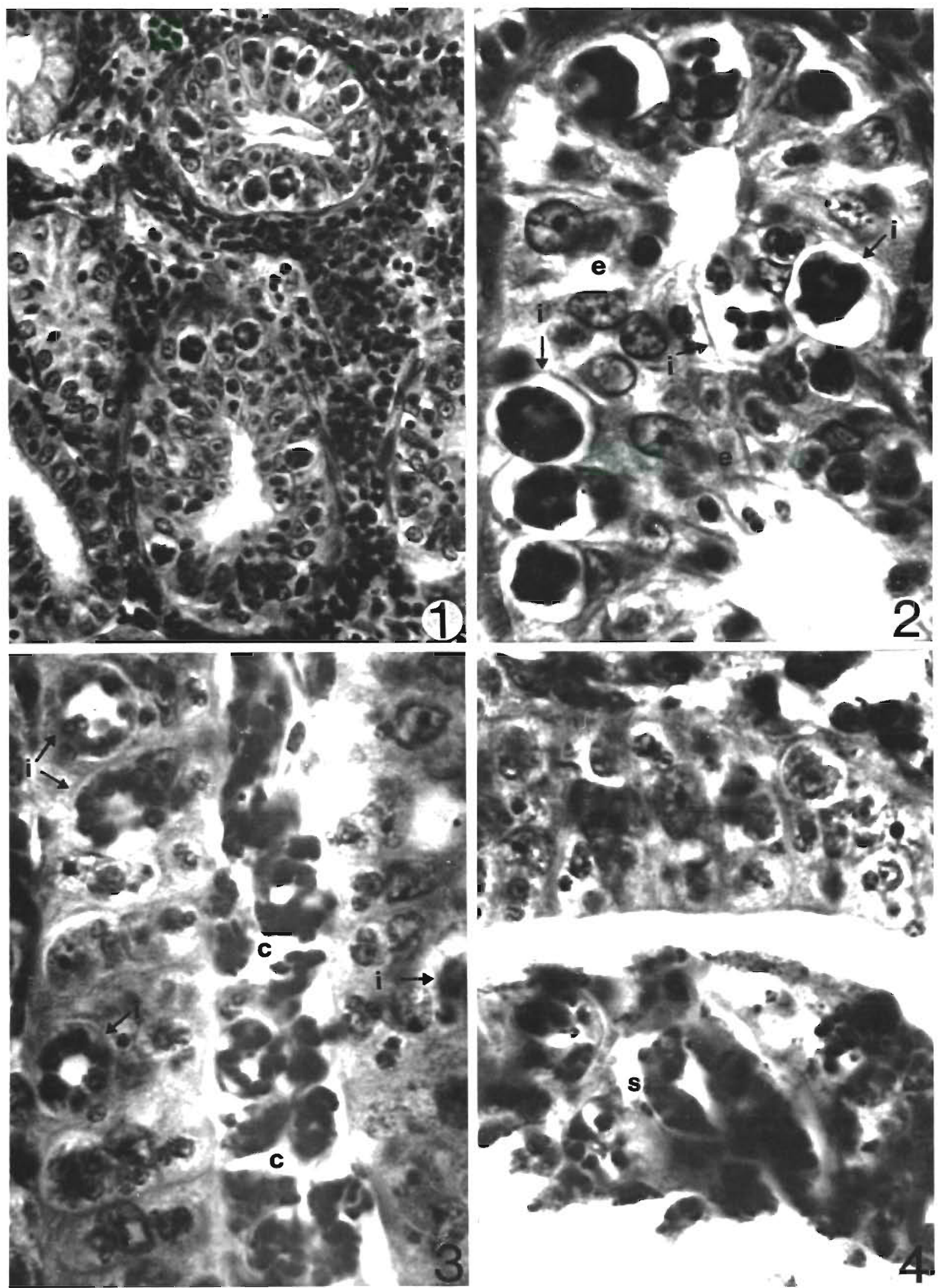
lial infection (Fig. 3). Round-shaped plasmodia measured up to $14 \mathrm{um}$ in diameter. Plasmodia occasionally contained primordia of spores or even a few mature spores (Fig. 4).

\section{Coelozoic plasmodia in ureters and urinary bladder of white bream}

Plasmodia found in ureters and urinary bladder were usually larger than those found in collecting tubules. Round-shaped plasmodia were 14 to $18 \mu \mathrm{m}$ in diameter and occurred freely in the lumen. Elongated plasmodia were 18 to $22 \times 10$ to $12 \mu \mathrm{m}$ in size and attached to the wall of ureters and urinary bladder, and often to the cuticie of Phyllodisiomum elongatum, a trematode parasitizing the ureters (Fig. 5). Similarly to the trophozoites, the plasmodia contained 10 to 14 nuclei. Plasmodia being at a more advanced stage of development contained primordia of spores or even mature spores. One plasmodium contained 1 to 3 spores (Fig. 6).

\section{Myxobilatus spores in ureters and urinary bladder of white bream}

The characteristic spores of Myxobilatus legeri were frequently seen in coverslip preparations of mucus squeezed out from ureters and urinary bladder, and examined by immersion microscopy. The spores were diverse in morphology and measured 10 to $12 \mu \mathrm{m}$ without the caudal projection. Their shape was greatly influenced by the osmolality of the medium: in samples diluted with tap-water they were round, whereas in untreated mucus they were mostly elongated. This difference in shape was apparent in specimens originating from the same fish. In general, however, the spores conformed to the description of $M$. legeri by Shulman (1966)

\section{Intracellular developmental stages in rudd}

In rudd, the location of intracellular trophozoites was the same as that found in white bream (Fig. 7). Trophozoites were morphologically similar to, but somewhat smaller (average diameter $8 \mu \mathrm{m}$ ) than, those seen in white bream.

\section{Coelozoic plasmodia in the lumen of renal tubules in rudd}

Young plasmodia occurred in the lumen of tubular segments showing intraepithelial infection also in rudd (Fig. 8). These plasmodia were morphologically identical to the intracellular trophozoites, but exceeded the latter in diameter (12 to $13 \mu \mathrm{m}$ ). However, they were smaller than the plasmodia found in similar location in white bream.

\section{Coelozoic plasmodia in the ureters and urinary bladder of other cyprinids}

In addition to white bream, coelozolc plasmodia were also found in ureters of bleak, roach, common bream and gudgeon, mostly in the locations described for white bream. In bleak and roach, however, mixed infections by coelozoic plasmodia and Trichodina urinaria were rather common (Fig. 9). Plasmodia found in rudd and bleak were smaller than those seen in white bream. The round-shaped plasmodia were 12 to $14 \mu \mathrm{m}$ and 10 to $13 \mu \mathrm{m}$ in diameter in rudd and bleak, respectively.

\section{Myxobilatus spores in ureters and urinary bladder of other cyprinids}

Spores seen in bleak, roach and common bream essentially corresponded to the criteria described by Shulman (1966) for Myxobilatus legeri. Considering results reported by Evlanov (1981) and Lom (1986), however, a detailed study of these spores is needed.

\section{DISCUSSION}

The present study indicates that Myxobilatus infection is very common in cyprinids living in natural waters of Hungary. Because of its seasonal incidence, however, infection can be diagnosed only in certain periods of the year. In early spring the prevalences of Myxobilatus infection in certain fish species approach $100 \%$. In the present work spore morphology has not been studied in detail. Therefore, no conclusions can be drawn as to whether or not the Myxobilatus stages

Figs. 5 to 9. Fig. 5. Myxobilatus legeri plasmodia (p) attached to cuticle of trematode Phyllodistomum elongatum in a white bream ureter; (su) ventral sucker of trematode $(H$. and $E$.),$\times 200$. Fig. $6 . M$. legeri plasmodia containing spores and pnmordia of spores in lumen of ureter from a white breami (s) spores $(\mathrm{H}$. and E.), $\times 1300$. Fig. 7. Renal tubule segment infected by $M$. legeri trophozoites from a rudd $(\mathrm{H}$. and E.), $\times 200$. Fig. 8. Detail of renal tubule from a rudd; note $M$. legeri trophozortes in epithelium and coelozoic plasmodia in lumen of the tubule $(\mathrm{H}$. and $\mathrm{E}), \times 500$. Fig. 9. Detail of ureter from a bleak; note simultaneous occurrence of Trichodina urinaria $(\mathrm{t})$ specimens and of $M$. legeri plasmodia $(\mathrm{p})$ in the lumen (H.. and E.), $\times 500$ 


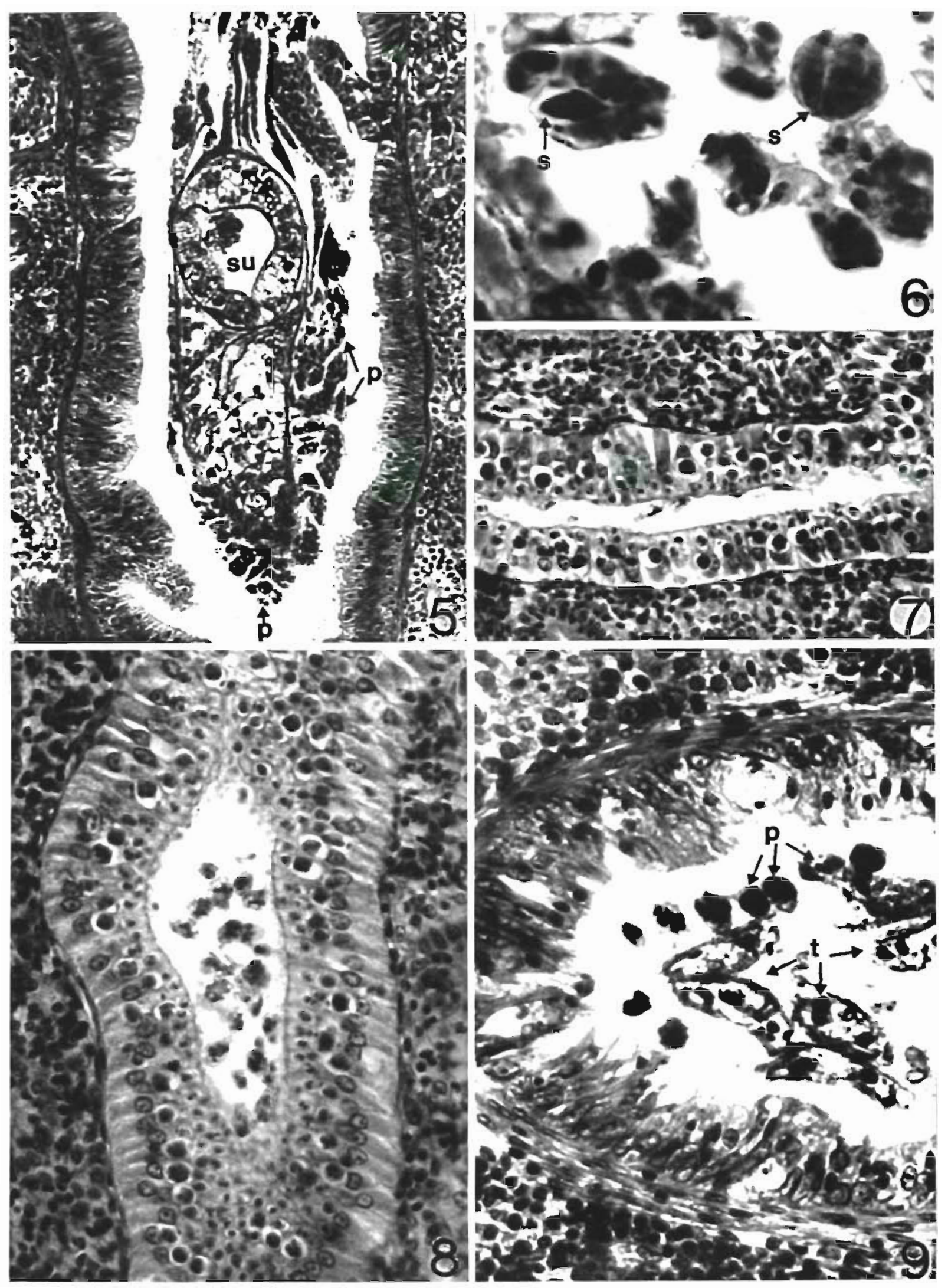


found in the different cyprinids represent separate species. Since the spores found in the present study satisfy the criteria described by Shulman (1966) for $M$. legeri (Cépède, 1905), they are regarded as developmental stages of $M$. legeri (sensu lato) until the results of more detailed studies are available. At the same time, it should be mentioned that from the morphological characteristics and developmental properties of Myxobilatus stages found in different fish species it seems highly probable that they represent separate species

According to Shulman $(1966,1984)$, apart from Myxobilatus gobii described by Evlanov (1981), M. legeri (Cépède, 1905) is the only Myxobilatus species parasitizing European cyprinids. So far this parasite has been reported to occur in roach, rudd. ide, bleak: white bream, common bream, blue bream Abramis ballerus, and even in the non-cyprinid stone loach Nemacheilus barbatulus. Lom (1986) found morphological differences between $M$. legeri spores collected from roach and those obtained from rudd, and questioned whether they represented the same species. He described the new parasite collected from the tench as a new species, M. nostalgicus

The present investigation revealed that the development of this myxosporean, formerly considered an exclusively coelozoic parasite, includes an early intracellular stage in the epithelium of collecting tubules of the kidney. In these epithelial cells develop the multinucleated trophozoites whose final stage is identical with plasmodia which live in the urinary tract and do not yet contain spores. During their growth, obviously due to the regenerating activity of the tubular epithelium and loss of function of the host epithelial cell, trophozoites are first pushed to the basal membrane, then, probably after death of the mother cell, are expelled into the lumen.

The development of Myxobilatus legeri (sensu lato) is characterized by distinct seasonality. The early stage of development occurs in autumn (and possibly in summer). Intraepithelial forms appear in late autumn and in winter, and change into coelozoic plasmodia in rudd in autumn; in other fish species, in winter and early spring. Within the coelozoic plasmodia spores are formed. Sometimes plasmodia occur freely in the lumen of tubules and ureters: at such times they are spherical. At other times plasmodia attach to the wall of the ureter, and assume an elongated shape. Depending on the intensity of infection and the possibility of drifting passively in the urinary passages, spore formation sometimes takes place in renal tubules, in other cases in ureter or urinary bladder. Except for rudd, spores usually appear in April; in May, Myxobilatus spores are demonstrable in the urinary tract only exceptionally Investigations made on large numbers of fish (not reported here because of their negative results) indicate that Myxobilatus infection cannot be demonstrated beyond May.

The type of development shown by Myxobilatus and Hoferellus species represents a middle course between myxosporeans developing in a single organ, within an enormous plasmodium (Myxobolus, Thelohanellus, Henneguya) and the Sphaerospora-type parasites. The development of Myxobolus-type parasites takes place at a given site of a given organ intracellularly or intercellularly throughout the cycle, from the time of colonisation up to spore formation. Contrarily, sphaerospores parasitizing the kidney develop in several successive stages in several different organs (swimbladder, eye socket), but primarily in the blood of the fish, whereas spore formation occurs in the renal tubules exclusively in a coelozoic manner (Kovács-Gayer et al. 1982, Csaba et al. 1984, Molnár 1984). In the type of development represented by Myxobilatus and Hoferellus species, first the histotropic phase occurs in the tubular epithelium, and this is followed by the coelozoic sporeformation stage in the lumen of tubules in the same organ. This statement is seemingly contradicted by results of Lom \& Dyková (1985) who described a tubulo-epithelial stage in the development of Sphaerospora renicola. The latter authors, however, considered these intracellular forms - referred to as 'Hoferellus' also by them - Sphaerospora stages of a blocked developmental cycle, and failed to recognize that these stages represent part of the developmental cycle of Hoferellus cyprini. Similarly, it is highly probable that the 'Hoferellus'-like organisms observed by Lom \& Dyková (1986) in the kidney of Leuciscus cephalus can be identified with intracellular Myxobilatus stages. The different Sphaerospora, Myxobilatus and Hoferellus species frequently occur as mixed infections. With knowledge of the seasonal development of Hoferellus and Myxobilatus spp., their differentiation from sphaerospores is easy in certain periods of the year. From May on, only sphaerospores occur up to early autumn when developmental stages of Hoferellus and Myxobilatus species appear. Another possible aid to differentiation is the fact that in fry, Sphaerospora infection is common, but neither MYXobilatus nor Hoferellus infection has been reported to occur in that age group thus far.

Intracellular development in epithelial cells of the secretory organs, and subsequent intraluminal stages of development are not exclusive peculiarities of Myxobilatus and Hoferellus species. A similar histozoic phase may exist in the development of other species so far considered to be exclusively coelozoic. It is known that simultaneously with the plasmodia of Chloromyxum spp. developing in the bile there are developmental stages in the wall of the gallbladder. Weissen- 
berg (1921) and Lom \& Dyková (1986) reported that in pike infected by Myxidium lieberkühni so-called nephrocystidia were formed in the glomerular endothelial cells. Furthermore, Kovács-Gayer \& Rátz (1987) described additional interstitial stages.

In my opinion, members of the genera Myxobilatus and Hoferellus are very similar both in morphology and development. The spore body is of similar structure. The single, but important, difference is that in Hoferellus spores the ribs running along the spore are continued on separate bristles, whereas Myxobilatus spores have 2 caudal projections. The development of the 2 genera is practically identical. Both parasite types have the unique property of forming spores in winter and early spring, and the development of both genera includes an intracellular stage taking place in the renal tubules (Ahmed 1973, Molnár \& Kovács-Gayer 1986. Molnár et al. 1986) and a coelozoic stage in ureters and urinary bladder.

In summary: in the majority of cyprinids, Myxobilatus spp. represent the same type as does Hoferellus in the genera Carassius and Cyprinus. On the basis of the morphological and developmental characteristics it would be reasonable to place the genus Hoferellus Berg, 1898 (syn. Mitraspora Fujita, 1912), together with the genus Myxobilatus Davis, 1944, in the family Myxobilatidae Shulman, 1953.

\section{LITERATURE CITED}

Ahmed, A. T A. (1973). Morphology and life history of Mitraspora cyprini Fujita parasitic in the kidney of goldfish. Jap. J. med. Sci. Biol. 26: 87-101

Clifton-Hadley, R. S., Bucke, D., Richards, R. H. (1984). Proliferative kidney disease of salmonid fish: a review. J. Fish Dis. 7: $363-378$

Csaba, G., Kovács-Gayer, É., Békési, L., Bucsek, M., Szakolczai, J., Molnár, K. (1984). Studies into the possible protozoan aetiology of swimbladder inflammation in carp fry. J. Fish Dis. 7: 39-56

Dykova, I., Lom, J. (1982). Sphaerospara renicola n. sp., a myxosporean from carp kidney and its pathogenicity. $Z$ ParasitenKde 68: 259-268
Evlanov, I. A. (1981). New species of myxosporeans from fish of the Kaliningrad region. Parasitologiya 15: 168-170 (Russian)

Kent, M. L., Hedrick, R. P. (1985). PKX, the causative agent of proliferative kidney disease (PKD) in Pacific salmonid fishes and its affinities with the Myxozoa. J. Protozool. 32 $254-261$

Kovács-Gayer, É., Csaba, G., Békési, L., Bucsek, M., Szakolczai, J., Molnár, K. (1982). Studies on the protozoan etiology of swimbladder inflammation in common carp fry. Bull. Eur. Ass. Fish Path. 2: 22-24

Kovács-Gayer, E., Rátz, F. (1987). Prevalence of Myxidium lieberkühni (Bütschli, 1882) in pike in Hungary. (Abstract) 2nd International Symposium of Ichthyoparasitology, Tihany, 27 Sep to 3 Oct, p. 48

Lom, J. (1986). Hoferellus cyprini (Doflein, 1898) Berg, 1898 (Syn. Mitraspora cyprini Fujita, 1912), Myxobilatus nostalgicus sp. n. and related species: partial revision of two Myxosporean genera. Folia Parasitol. 33: 289-296

Lom, J., Dykova, I. (1985). Hoferellus cyprini Doflein, 1898 from carp kidney: a well established myxosporean species or a sequence in the developmental cycle of Sphaerospora renicola Dykova and Lom, 1982? Protistologica 21: 195-206

Lom, J., Dykova, I. (1986). Comments on Myxosporean life cycle. Symp. Biol. Hung. 33: 309-318

Molnár, K. (1980). Renal sphaerosporosis in the common carp Cyprinus carpio L. J. Fish Dis. 3: 11-19

Molnár, K. (1984). Experimental evidence that protozoa causing swimbladder inflammation in common carp (Cyprinus carpio) are stage of Sphaerospora renicola. Bull. Eur. Ass Fish Path. 4: 14-15

Molnár, K., Csaba, G., Kovács-Gayer, É. (1986). Study of the postulated identity of Hoferellus cyprini (Doflein, 1898) and Mitraspora cyprini Fujita, 1912. Acta Vet. Hung. 34 175-181

Molnár, K., Kovács-Gayer, É. (1986). Observations on the intracellular and coelozoic developmental stages of Hoferellus cyprini (Doflein, 1898) (Myxosporea, Myxozoa). Parasitol. Hung. 19: 27-30

Shulman, S. S. (1966). Myxosporidia of the fauna of the USSR Publ. House Nauka, Moscow-Leningrad. (Russian)

Shulman, S. S. (1984). Parasitic protozoa. In: Bauer, O. N. (ed.) Key to the parasites of freshwater fauna of the USSR, Vol. I. Publ. House Nauka, Leningrad. (Russian)

Weissenberg, R. (1921). Cited in Weissenberg, R. (1923). Weitere Studien über intracellulären Parasitismus. Ein Myxosporidienartiger Organismus als echter Zellparasit der malphigischen Körperchen der Hechtniere. Arch. mikrosk. Anat. Entwicklungsmech., I Abt. 97: 431-485 